\title{
Mevcut Binalarda Isı Yalıtımı Uygulamalarının Değerlendirilmesi
}

\author{
Deniz BAYRAKTAR* ${ }^{*}$ Emre Artun BAYRAKTAR \\ Antalya Valiliği Çevre ve Şehircilik İI Müdürlüğü, Antalya \\ Geliş Tarihi (Received): 11.02.2016, Kabul Tarihi (Accepted): 14.03.2016 \\ $\square$ Sorumlu Yazar (Corresponding author)*:_deniz_ceditoglu@hotmail.com \\ (6) +902423218006 且 +902423217832
}

\section{öz}

Ülke olarak enerji intiyacımızın büyük bir kısmını ithal etmekte olup, nüfus artışına bağlı olarak enerji kaynaklarının temini için yüklü miktarda kaynak harcamaktayız. Yaşadığımız bölge ve coğrafi özellikler itibari ile enerji kaynaklarına ulaşım kolay olmasına rağmen, kıta siyasi haritası anlamında enerji kaynaklarının ülkeler arasında yaptırım aracı olarak değerlendirilmesi sorun teşkil etmektedir. Bu nedenle, enerji tüketiminde israfın önlenmesi bir zorunluluktur. Bu çalışmada, enerji verimliliği kapsamında mevcut binalarda ıSı yalıtımı uygulamaları hem mühendislik bilimi hem de mevzuat anlamında değerlendirilerek karşılaşılan sorunlar üzerine öneriler sunulmuştur.

Anahtar Kelimeler: Isı yalıtımı, mantolama, enerji verimliliği

\section{To Assess the Applications of Thermal Insulation in Existing Buildings}

\section{ABSTRACT}

As a country, importing the majority of our energy needs, we spend a large quantity of resources for the supply of the sources of energy depending upon the increase of population. Although it is easy to reach the sources of energy in respect of the region we live and the geographical features, it poses a problem to evaluate the sources of energy as a sanction mediation among countries in accordance with continent political map. Therefore, it is an obligation to prevent profusion in the energy consumption. In this study, within the scope of energy efficiency, some suggestions on the encountered problems about the applications of the thermal insulations in existing buildings have been presented by being evaluated both in accordance with the engineering science and legislation.

Keywords: Thermal insulation, jacketing of existing buildings, energy efficiency

\section{GíRiş}

Giderek artan enerji ihtiyacını karşılamak amacıyla fosil yakıtlar (petrol ürünleri, kömür vb.) ile enerji üretmek yerine, enerji tüketiminde israfın önlenmesi ve yenilenebilir enerji kaynaklarının (hidrolik, güneş, rüzgar, termal kaynaklar vb.) kullanılmasının yaygınlaştırılması zorunluluk halini almıştır. Dünya üzerindeki enerji kaynaklarının hızla tükenmesi ile birlikte tüm devletler enerji intiyaçlarını kontrol altına alma ve enerjiyi etkin kullanma arayışı içine girmişlerdir (Şenkal, 2005). T.C. Enerji ve Tabii Kaynaklar Bakanlığı 2014 yılı faaliyet raporuna göre, 2014 yılı sonu itibarıyla ülkemizin kurulu gücünün \% 40,3'ünü yenilenebilir enerji, \% 59,7'sini diğer kaynaklar oluşturmaktadır. Ülkemizde enerjinin \% 35'i binalar 
tarafından tüketilmektedir. Bu tüketilen enerjinin ise \% 65 'i binalarda ısıtma, soğutma ve havalandırma amacıyla harcanmaktadır (Yaman ve ark., 2015).

Binaların ısıtılması ve soğutulmasında, aydınlatmada güncel yaşamda gerekli enerji miktarını sınırlamak, minimum seviyeye indirmek, dolayısıyla enerji tasarrufu sağlamaya yönelik önlemler almak zorunludur. Binalarda ısı kayıplarının önüne geçmek için gerçekleştirilen ısı yalıtımı bu önlemlerden biridir (ÇŞB, 2015). Yapılarda Isı yalıtımı uygulamaları ile binaların ısıtılmasında kullanılan enerji miktarları sınırlandırılabilir, dolayısıyla enerji tasaruflu yapılar üretilebilir (Koçu ve Dereli, 2010). Doğru bir ısı yalıtımı ile binalarda, ortalama \% 30-60 oranında enerji tasarruf edilebilecektir (ÇŞB, 2015). Ülkemizde, binalarda ISI yalıtımı yapılmasına dair zorunluluğun 08.05.2000 tarihli "Binalarda Isı Yalıtım Yönetmeliği" ile başladığı ve mevcut bina stoğu gözönüne alındığında, mevcut binalarda ISı yalıtım uygulamalarının önemi ortaya çıkmaktadır.

\section{ISI YALITIMININ TANIMI VE AMACI}

Yapılarda ve tesisatlarda ISı kayıp ve kazançlarının sınırlandırıması için yapılan işleme "ısı yalıtımı" denir. Teknik olarak, Isı yalıtımı, farklı sıcaklıktaki iki ortam arasında ISı geçişini azaltmak için uygulanır (URL-1, 2016). Isı yalıtımsız binalarda ısı kayıplarının yüksek olması sebebiyle daha çok enerji harcanmakta ve yakıt tüketimi artmaktadır (Koçu ve Dereli, 2010). Tüketilen yakıtın fazla olması binanın kullanım maliyetini yükseltirken, yakıtların atmosfere verdikleri zararlı gazlar nedeniyle de çevre kirliliğini arttırmaktadır (Şenkal, 2005). Binalarda ısı kayıp ve kazançlarının düşürülmesi, ısıtma enerjisi harcamalarının minimum düzeye indirgenmesi amacıyla ısı yalıtımı, binaların dışarıya veya garaj, depo gibi ısıtılmayan bölümlerine bakan duvar, çatı, döşeme, cam, doğrama ve ısıtma, soğutma, havalandırma vb. tesisatlarına uygulanır (URL-2, 2016; Oral ve Manioğlu, 2010).

\section{ÜLKEMIZDE ISI YALITIMININ TARIHSEL GELIŞiMi}

Ülkemizde yalıtım üzerine yayınlanan ilk mevzuat 1970 yılında yürürlüğe giren "TS 825 Binalarda Isı Yalıtım Kuralları" standartıdır. Söz konusu standart 1998 yılında revize edilmiştir. 1981 yılında "Isı Yalıtım Yönetmeliği" yürürlüğe girmiştir. Binalarda ısı yalıtımı yapılmasına dair zorunluluk 08.05.2000 tarihli "Binalarda Isı Yalıtım Yönetmeliği" ile başlamış olup, 14.06.2000 tarihine kadar inşaat ruhsatı alınmış özel mülkiyete sahip binalarda ısı yalıtımı yapılmasına dair bir zorunluluk bulunmamaktaydı (URL-3, 2016). 09.10.2008 tarih ve 27019 sayılı Resmi Gazete'de yayımlanarak "Binalarda Isı Yalıtımı Yönetmeliği" yürürlüğe girmiştir. Bu yönetmelik ile 08.05.2000 tarihli yönetmelik yürürlükten kaldırımıştır (BIB, 2008).

Enerjinin etkin kullanılması, israfının önlenmesi, enerji maliyetlerinin ekonomi üzerindeki yükünün hafifletilmesi ve çevrenin korunması amacıyla 02.05.2007 tarih ve 26510 sayılı Resmi Gazete'de yayımlanarak "5627 Sayılı Enerji Verimliliği Kanunu" yürürlüğe girmiştir (ETKB, 2007). Akabinde, Mülga Bayındırlık ve İskan Bakanlığı'nca hazırlanan "Binalarda Enerji Performansı Yönetmeliği” 05.12.2008 tarih ve 27075 sayılı Resmi Gazete'de yayımlanarak yürürlüğe girmiştir (BIB, 2008).

Isı yalıtımının en önemli kısmını oluşturan dış cephe ısı yalıtımı gelişmiş ülkelerde 1970'li yıllarda uygulamaya başlanmış olmasına rağmen, ülkemiz 1991 yılında ithal ürünlerle dış cephe ısı yalıtım malzemeleri ile tanışmıştır. Yine 1990'ı yılların başında önemli ıSı kayıplarının yaşandığı pencere doğramalarında çift cam ünitesi kullanımı da başlamıştır (Yaman ve ark., 2015).

\section{ISI YALITIM UYGULAMALARI}

\section{Döşemelerde ısı yalıtımı}

Toprak zemin ile temasta bulunan döşemelerde, asmolen arakat-tavan döşemelerde ve Isıtılmayan hacim üstü döşemelerde uygulanan ISı yalıtımıdır. Döşeme betonunun yüzeyi düzgün, temiz, toz ve atıklardan arındırımış olmalıdır. Şap kalınlığı, döşeme kaplaması ve yükler gözönüne alınarak seçilecek ısı yalıtım malzemesi yeterli basma mukavemetine sahip olmalıdır (ÇŞB, 2015).

\section{Dış duvar ısı yalıtımı}

Bina dış duvarlarında iç veya dış cephelerden ısı yalıtımı yapılmasıdır. Kullanılacak olan ISı yalıtım malzemelerinin özellikleri, "Binaların Yangından Korunması Hakkında Yönetmelik" hükümlerine uygun olmalıdır. Yalıtım levhaları arasında boşluk kalmamalıdır. Gerekli olan kısımlarda subasman ve köşe profilleri kullanılmalıdır (ÇŞB, 2015).

\section{Tavan ISı yalıtımı}

Çatı arası kullanılan-kullanılmayan çatılar ile üzerinde gezilebilen-gezilemeyen ters ve geleneksel teras çatılarda ISI yalıtımı uygulamasıdır. Çatılarda ISI yalıtımı malzemesi mertek arasına, mertek üzerine veya mertek altına uygulanabilir. Mertek üzeri veya çatı üzeri uygulamalarda rijit levhalar, mertek arası uygulamalarda mineral yünler kullanılmalıdır (ÇŞB, 2015). 


\section{Pencerelerde Isı yalıtımı}

Pencere camlarının çift ve üçlü cam olarak kullanılmasının yalııma katkısı yüksek olacaktır. Günümüzde cam üniteleri çift cam ve üçlü cam olarak üretilmektedir. Düz çift cam üniteleri, yerini ısı kontrol kaplamalı ve ısı-güneş kontrol kaplamalı çift veya üçlü cam ünitelerine bırakmaktadır. Isı ve güneş kontrol kaplamalı cam üniteleri kullanımı ile de ıSı kayıpları, standart çift cam ünitelere kıyasla \% 50 oranında azalır (ÇŞB, 2015).

\section{Tesisatlarda ısı yalıtımı}

Isıtma veya soğutma tesisatında Isıtılmayan veya soğutulmayan hacimlerden geçen boru veya kanallarının yalıtım malzemeleriyle kaplanması ile yapılır. Soğutma ve ısıtma tesisatlarının ısı yalıtımı ile enerji tasarrufu sağlanır ve buna bağlı olarak işletme maliyeti azalır (URL-1, 2016).

\section{ISI YALITIM MALZEMELERI}

Bir malzemenin, ISı yalıtım malzemesi olarak değerlendirilebilmesi için ISO ve CEN Standartlarına göre malzemeye ait ısıl iletkenlik katsayısının $(\lambda) 0,065$ $\mathrm{W} / \mathrm{m} . \mathrm{K}$ değerinden küçük olması gerekmektedir. Yalıtım malzemesinin ısıl iletkenlik katsayısı ne kadar küçük ise Isı geçişine karşı o oranda yüksek direnç gösterir (Yaman ve ark., 2015). Ülkemizde sıklıkla kullanılan ISı yalıtım malzemelerinin Isı iletkenlik katsayısı $(\lambda)$ değerleri ve yangına tepki sınıfları Tablo1 'de gösterilmiştir.

Tablo 1. Isı yalıtım malzemelerine ait teknik değer ve aralıklar (ÇŞB, 2015)

\begin{tabular}{|c|c|c|}
\hline Isı Yalıtım Malzemesi & Isıl İletkenlik Katsayısı & Yangına Tepki Sınıfı \\
\hline Ekstrüde polistren köpük (XPS) & $0,030-0,040$ & D-E \\
\hline Ekspande polistren köpük (EPS) & $0,035-0,040$ & D-E \\
\hline Cam yünü & $0,035-0,050$ & $\mathrm{~A} 1-\mathrm{A} 2^{*}$ \\
\hline Taş yünü & $0,035-0,050$ & $\mathrm{~A} 1-\mathrm{A} 2^{*}$ \\
\hline Poliüretan (PUR) ve poliizosüyenürat (PIR) sert köpükler & $0,025-0,040$ & $B-C-D^{* *} / D-E^{* * *}$ \\
\hline Fenol köpüğü (PF) & $0,030-0,045$ & $B-C-D$ \\
\hline Cam köpüğü (CG) & $0,045-0,060$ & $\mathrm{~A} 1-\mathrm{A} 2$ \\
\hline Ahşap yünü (WW) & $0,035-0,076$ & $B-C-D$ \\
\hline Genleştirilmiş perlit (EPB) & $0,045-0,065$ & A1 \\
\hline Genleştirilmiş mantar levhalar (ECB) & $0,045-0,055$ & C-D-E \\
\hline Ahşap lifli levhalar (WF) & $0,035-0,070$ & C-D-E \\
\hline Gazbeton ISı yalıtım levhası & $0,042-0,050$ & A1 \\
\hline
\end{tabular}

Isı yalıtım malzemelerinde farklı uygulama alanlarına göre aranan özellikler, malzemenin Isıl iletkenlik katsayısı, yoğunluğu, yangın sınıfı, sıcaklık dayanımı, mekanik dayanımı, buhar difüzyon direnci, su emme kapasitesi ve boyutsal kararlılıktır (Yaman ve ark., 2015).

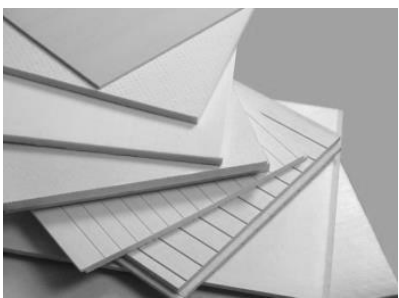

a) XPS ısı yalıtımı levha örneği

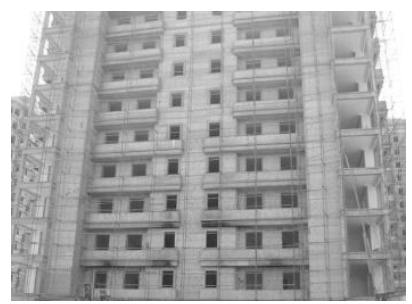

b) Dış cephe mantolama örneği

Ülkemizde mevcut binaların ISI yalıtımı uygulamalarında sıkça kullanılan malzemeler, ekstrüde polistren köpük (XPS) ve ekspande polistren köpük (EPS)'tür (Şekil 1). Bu malzemeler sıklıkla, dış cephelerde mantolama, toprakla temas eden yüzeylerde koruyucu tabaka, binaların bodrum kat döşemeleri ile geleneksel teraslarda ısı yalıtımı ve dekoratif amaçlı dış cephe uygulamalarında kullanılmaktadır.

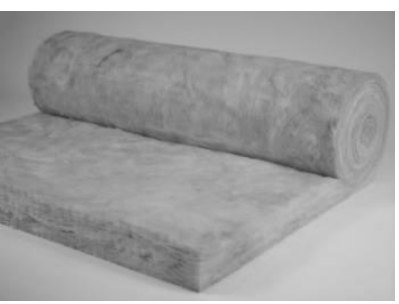

c) Camyünü çatı şiltesi örneği

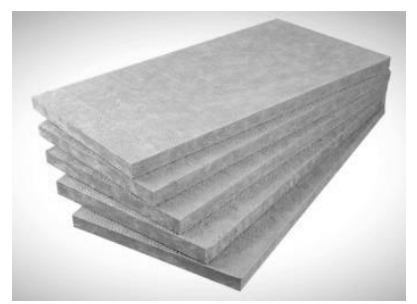

d) Levha taşyünü örneği

Şekil 1. Isı yalıtım malzemesi örnekleri (URL-4, 2016; URL-5, 2016) 
Camyünü, taşyünü ve ahşap yünü yalıtım malzemeleri açık gözenekli malzemelerdir (ÇŞB, 2015). Bu malzemeler genellikle dış cephe mantolama, çatı döşemesi üzerinde şilte formunda ısı yalıtımı ve boru formunda tesisat yalıtımı uygulamalarında tercih edilmektedir. Ayrıca, taşyünü ve camyünü, ses yalıtımı amacıyla da kullanılmaktadır. Gazbeton ısı yalıtım levhası, kuvarsit veya kum ile çimento, kireç ve suyun karışımından elde edilen ISı yalıtım malzemesidir. Bu ürün, binaların ıSı yalııımı amacıyla hem dış hem de iç yüzlerinde kullanılabilmektedir.

\section{MEVCUT BINALAR IÇiN MEVZUAT HÜKÜMLERI}

05.12.2008 tarihinde yürürlüğe giren "Binalarda Enerji Performansı Yönetmeliği”, binaların mimari yapısından, ısıtma sistemlerinin seçimine, ülke ekonomisine getireceği katkıdan ve en önemlisi sağlıklı bir çevre yaratmasına kadar pek çok alanı kapsamaktadır (Koçu ve Dereli, 2010). Yönetmelik kapsamında yeni ve mevcut binalarda enerji performansının yeterli düzeye getirilebilmesi için mimari proje tasarım ve uygulama esasları, ISI yalıtım esasları, ısıtma, soğutma, havalandırma ve iklimlendirme, sıhhi sıcak su hazırlama esasları ile elektrik tesisatı ve aydınlatma sistemleri hakkında usul ve esaslar belirtilmiştir.

Yönetmeliğin yürürlüğe girdiği tarih olan 05.12.2009 tarihinden sonra yapı ruhsatı alan binalar yeni bina, öncesinde yapı ruhsatı alan binalar mevcut bina olarak değerlendirilmektedir. Ancak, Enerji Kimlik Belgesi uygulamalarında, 01.01.2011 tarihinden sonra yapı ruhsatı alan binalar yeni bina, bu tarihten önce yapı ruhsatı alan binalar mevcut bina olarak işlem görür (URL-3, 2016).

Mevcut binalarda enerji performansı yönetmeliği kapsamında;

a) Mevcut binaların, dış cephe duvarlarında ISı yalıımı, ısıtma sisteminde kazan değişikliği, ferdi ve merkezi ısıtma sistemleri arasında dönüşüm yapılması, merkezi soğutma sistemi kurulması, kojenerasyon sistemi kurulması veya yenilenebilir enerji kaynaklarından elektrik üretilmesi ile ilgili konularda tadilat yapılması halinde, uygulama projesi hazırlanır ve yapı kullanım izni veren ilgili idare tarafından onaylanır ve uygulanması sağlanır (BIB, 2008).

b) Kullanılması planlanan Yapı ve Yalıtım Malzemelerinin $C E$ veya $G$ uygunluk işareti ve uygunluk beyanı veya belgesi alması zorunludur (BIB, 2008). c) Yönetmeliğin 12. Bölümünde "Enerji Kimlik Belgesi" düzenleme usul ve esasları belirtilmiştir. Mevcut binalar için "5627 sayılı Enerji Verimliliği Kanunu'nun" geçici 6. Maddesinin ikinci fıkrası gereğince 02.05.2017 tarihine kadar enerji kimlik belgesi düzenlenmelidir.

\section{MEVCUT BINALARDA ENERJI KIMLIK BELGESI VE ISI YALITIM UYGULAMALARI}

Enerji Kimlik Belgesi, binada kullanılan sistemlere dayalı olarak enerji kullanım alanlarına (ısıtma, sıhhi sıcak su, soğutma, havalandırma ve aydınlatma sistemleri) ait yıllık enerji tüketim değerleri ve bu değerlere dayalı olarak herbir enerji kullanım alanına ait enerji performansı sınıfının ve binaya ait sera gazı emisyonu ile binada mevcut ise yenilenebilir enerji kullanım oranlarını içeren belgedir.

Ayrıca, belgeyi düzenleyen yetkililerce, binanın "Enerji Performans Sınıfının" yükseltilmesi ve "Sera Gazı Emisyonu oranının" azaltıması amacıyla binanın enerji performansı sınıfına göre hazırlanan öneri sayfasını içermektedir. "Binalarda Enerji Performansı Yönetmeliği”nin 27. Maddesine göre yeni binalar C sınıfı enerji kimlik belgesine sahip olması gerekirken mevcut binalar A ile $G$ sınıfı aralığında herhangi bir enerji sınıfına sahip enerji kimlik belgesine sahip olabilirler (URL-3, 2016).

Mevcut binalarda, yapılması planlanan ISI yalıtımı uygulamaları için bina sahip ve yöneticilerinin muhtelif yasal yükümlülükleri mevcuttur. Bu kapsamda, ilk olarak "Enerji Kimlik Belgesi"nin, Enerji ve Tabii Kaynaklar Bakanlığı'na bağlı Yenilenebilir Enerji Genel Müdürlüğü'nce (YEGM) yetkilendirilen danışmanlık şirketleri aracılığıyla düzenlettirilmesi gerekmektedir. Aslında mevzuat kapsamında, mevcut binalar için 02.05.2017 tarihine kadar enerji kimlik belgesinin düzenlenmesi yeterlidir ve mevzuatta enerji performansı sınıflarına ait herhangi bir hüküm bulunmamaktadır. Ancak, ülkemizde tüketilen enerjinin \%85'i gibi büyük bir kısmının ısıtma amaçlı kullanıldığı gözönüne alındığında tüm binalarda ISı yalıtım uygulamalarının yapılması bir gerekliliktir (Şenkal, 2005).

"Binalarda Enerji Performansı Yönetmeliği"nin 5. Maddesinde mevcut binalarda dış cephe duvarlarında ISI yalıtımı konusunda tadilat yapılması halinde uygulama projelerinin hazırlanması ve yapı kullanım izni veren ilgili idare tarafından onaylanması akabinde uygulanması gerektiği açık bir şekilde belirtilmektedir (BIB, 2008). Ülkemizde, mevcut binalarda ISı yalıtımı uygulamaları çoğunlukla dış cephelerde mantolama 
imalatı olarak yapılmaktadır. Bu kapsamda, bina sahip ve yöneticilerince uygulama projelerinin hazırlatılarak tadilat ruhsatı için ilgili idareye başvurulması ve gereken tadilat ruhsatı onayının alınması akabinde uygulamaya başlanması gereklidir.

Ülkemizde mevcut binalara yapılan ISI yalıtım uygulamaları için bina sahip ve yöneticilerinin, eksik ve yanlış bilgilerden dolayı yalıtım uygulamalarını mühendislik hizmetinden ve denetimden yoksun, doğrudan ticari kaygı ile hareket eden, işinde uzman olmayan kişi veya taşeron firmalara yaptırdıkları bilinen bir gerçektir. Oysa ki, binalarda enerji tasarrufunun temeli; doğru detay, nitelikli malzeme kullanımı ve doğru bir işçilikle hatasız bir uygulamaya dayanır (Koçu ve Dereli, 2010). Isı yalıtım malzemelerinin iş̧̧ilik hataları olmadan uygulanması, kullanım yeri ve malzeme özelliklerinin gözönünde bulundurularak seçilmesi önem arz etmektedir.

Proje kapsamında dahi olsa yapılan ISı yalıtımı imalatlarında, işçilik hatalarının oluşması sonucunda malzemeden beklenilen Isıl performans sağlanamayabilir. İşçilik hatalarının düşük seviyede kalması için yalıım uygulamalarının, ustalık belgesine sahip konusunda uzman kişilerce yapılması gerekmektedir.

TS 825 "Binalarda Isı Yalıtımı Kuralları" standardında ısıtma uygulamaları için 4 derece-gün bölgesi tanımlanmıştır (TSE, 2013). Tüm bölgelerde kullanılabilecek tek bir Isı yalıtım malzemesi yoktur (Şenkal, 2005). Bina cephelerinde kullanılacak ISI yalıtım malzemesi seçiminde coğrafi ve iklimsel faktörler göz önünde bulundurulmalıdır.

\section{MEVCUT BINALARDA ISI YALITIM UYGULAMALARINDA KARŞILAŞILAN SORUNLAR}

Mevcut binalarda ISı yalıtımı uygulamalarında bazı sorunlar ile karşılaşılmaktadır. Bu sorunlar aşağıda maddeler halinde anlatılmış ve öneriler sunulmuştur.

\section{Pencere kenarları ve denizlikleri}

Pencere kenarlarında köşe profili ve takviye bandı kullanılmaması durumunda, yalıtım malzemesi yarılarak cepheden ayrılabilir. Bu nedenle, gerekli detay imalatların yapılması gereklidir (Şekil 2).

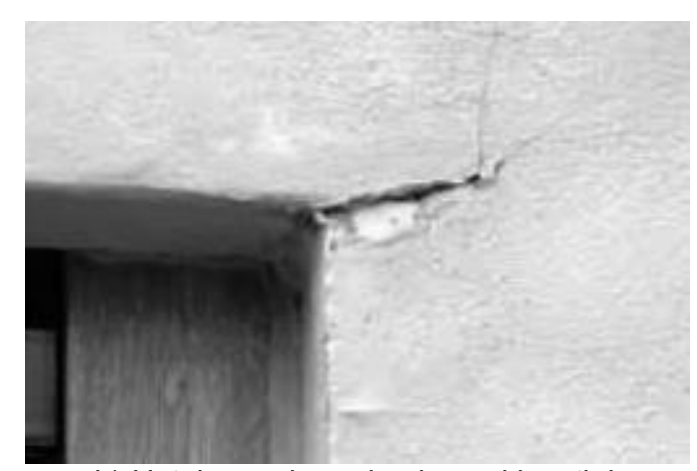

b) Hatalı uygulamadan kaynaklı çatlak

Şekil 2. Pencere kenarlarında köşe profili ve takviye bandı uygulama örnekleri (ÇŞB, 2015)

Pencere denizlikleri-damlalıkları, tercih edilen ısı yalıtım malzemesinin kalınlığından dolayı kapanabilmektedir. Denizlik damlalıklarının kapanması neticesinde yağmur suları cephe kaplamasına akmakta ve dış cephe boyası zarar görmektedir (Şekil 3a).

Bu durumun oluşmaması için;

a) Mantolama imalatı esnasında dış denizlikler sökülüp, yalıtım malzemesi kalınlığına göre ölçülendirilmiş yeni denizliklerin yerine tespiti yapılabilir, b) Mevcut denizliklere, pencere yalıtım bandı ve denizlik-duvar birleşim profilleri kullanılarak PVC veya alüminyum denizlik uzatma profilleri yerleştirilebilir (Şekil 3b),

Yalıtım malzemesinin denizlik üzerine uzatılarak sırasıyla donatı filesi ve levha sıvasının uygulanıp son detay olarak da alüminyum denizlik profili (Şekil 3c) kullanılabilir. 


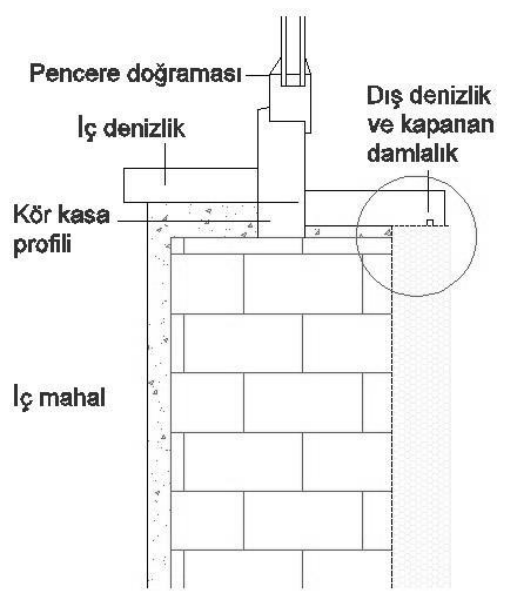

a) Mantolama imalatı sonrası denizlik damlalıklarının kapanması hali

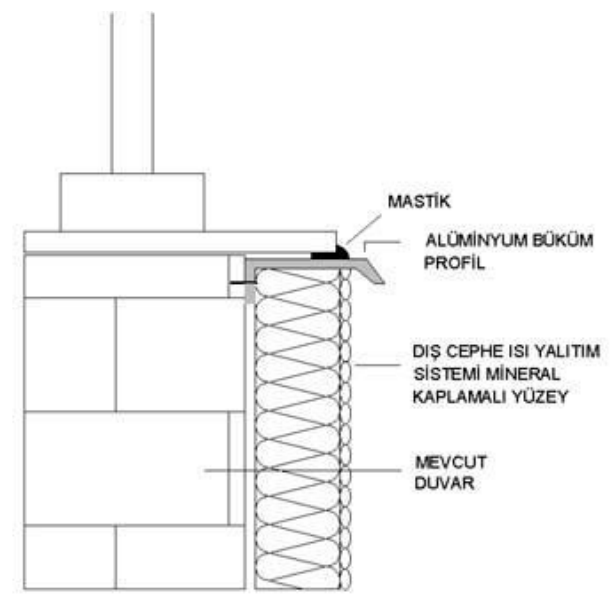

b) Alüminyum denizlik uzatma profili uygulama detayı (URL$6,2016)$

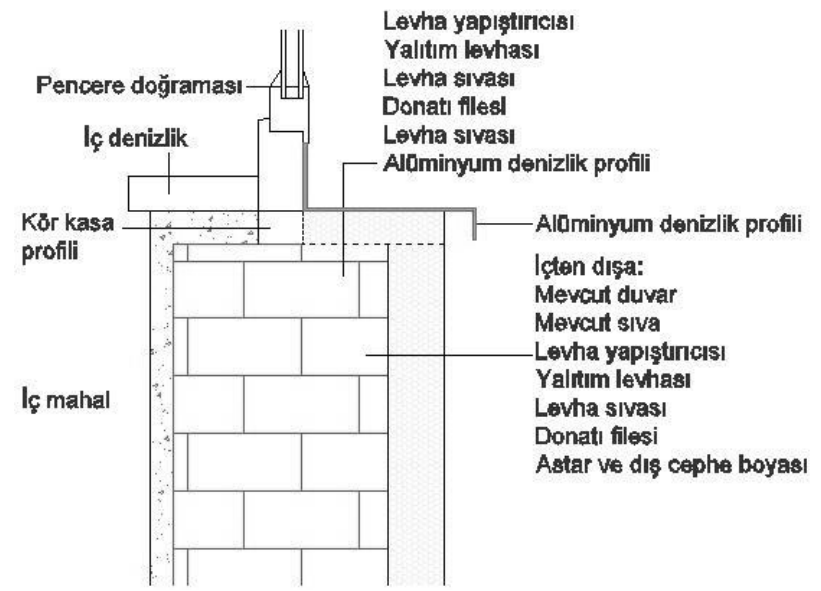

c) Alüminyum denizlik profili uygulama detayı

Şekil 3. Pencere denizliklerine uzatma profilleri uygulama detayları

\section{Tamamlayıcı profillerin kullanımı}

Dış cephe yalıtım uygulamasının doğru bir şekilde tamamlanması amacıyla, muhtelif profillerin kullanımına intiyaç vardır. Tamamlayıcı profillerin kullanılmaması durumunda, bina dış cephesi estetik görünümden uzaklaşacaktır. $\mathrm{Bu}$ nedenle yalıtım levhalarının başlangıçta teraziye alınabilmesi için subasman profilleri, kapı ve pencere merkezleri için kenar ve kemer profilleri, farklı kaplama malzemesine geçiş durumlarında yan kaplama profilleri, binada dilatasyon olması durumunda dikey veya düz geçişli dilatasyon profili, mimari estetik yönünden fuga profilleri, bina köşelerinde düz veya açılı köşe profilleri kullanılmalıdır (Şekil 4). 


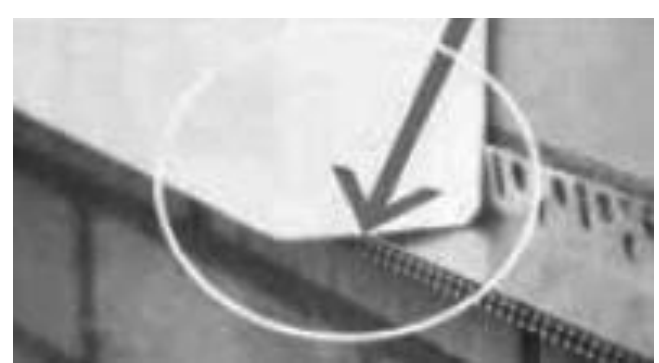

a) Subasman profilinin hatalı kullanımı

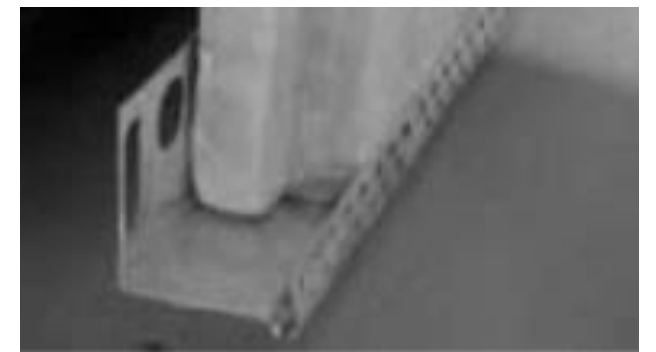

b) Subasman profilinin doğru kullanımı
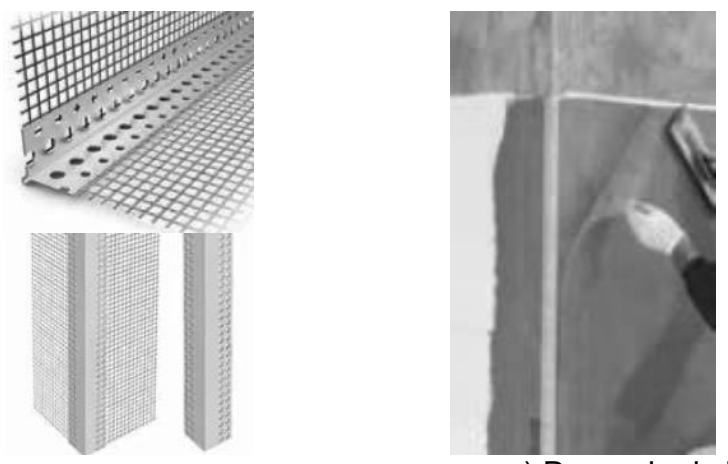

c) Dış cephede köşe profili uygulama örneği
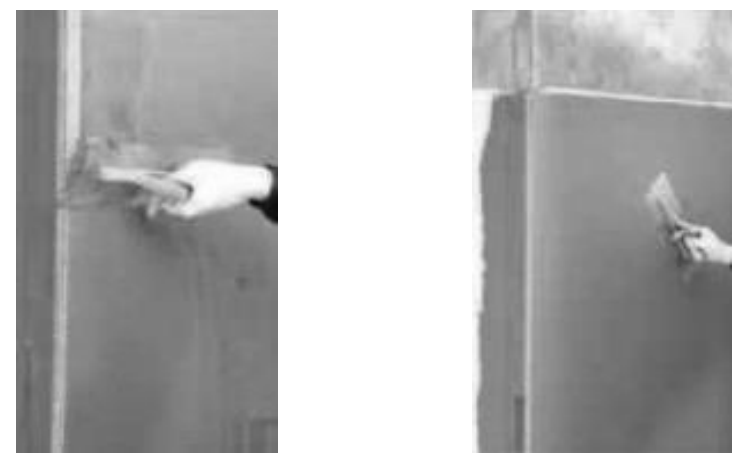

Şekil 4. Subasman ve dış cephe profilleri uygulama örnekleri (ÇŞB, 2015)

\section{Sistemin tamamlanması}

Ülkemizde, mevcut binalar için ISı yalıtımı uygulamalarının dış cephe yalıtımından ibaret olduğu görüşü hakimdir. Ancak, ISı yalıtımından beklenilen verimin binada ISI köprülerine mahal vermeden sağlanabileceği unutulmamalıdır. Bu doğrultuda, bina bodrum veya zemin katlarında garaj-depo gibi ısıtılmayan mahallerin, çatı veya teras döşemelerinin, tesisat boru ve kanallarının ve kapı-pencere doğramalarının da yalıtıması gereklidir.

\section{İş iskelesi}

18.04.2014 tarih ve 28976 sayılı Resmi Gazete'de yayımlanan "İş Sağlığı Ve Güvenliğine İlişkin İşyeri Tehlike Sınıfları Tebliğinde Değişiklik Yapılmasına Dair Tebliğ"e göre dış cephe ısı yalıtımı uygulamaları ve inşaat iş iskelesi işleri çok tehlikeli sınıfta yer almaktadır (ÇSGB, 2014). Dış cephede yapılması planlanan mantolama imalatı için kurulacak olan iş iskelesi, ilgili standart ve yönetmeliklere uygun şekilde olmalıdır. Aynı zamanda, çalışma esnasında yüksekten düşebilecek el aletleri, malzemeler gibi maddeler için de önlem alınması gereklidir. Alınması gereken önlemlerin denetlenebilir olması açısından ilgili idarelere başvurulması uygun olacaktır.

\section{Projelendirme ve tadilat ruhsatı}

Mevcut binalarda yapılan dış cephe ISı yalıtım uygulamaları "Binalarda Enerji Performasnı Yönetmeliği” kapsamında tadilat ruhsatı gerektirmektedir (BIB, 2008). Oysa ki ülkemizde mevcut binalardaki mantolama uygulamaları için tadilat ruhsatının alınması gerektiğinin çok az sayıda kişi tarafından bilindiği ortadadır. İmalatların ve çalışma esnasında iş sağlığı ve güvenliği kapsamında yapılan uygulamaların denetlenebilir olması, işçilik ve detay eksikliği hatalarının engellenmesi amacıyla uygulamaya esas projelerin oluşturularak ilgili idarelere ruhsat onayı için başvurmak büyük önem arz etmektedir.

\section{SONUÇLAR VE ÖNERILER}

Ülkemizde son yıllarda, yeni ve mevcut binalarda ISı yalıtım uygulamalarında artış yaşanmıştır. "Binalarda Enerji Performansı Yönetmeliği”nin yürürlüğe girdiği 2008 yılından bu yana geçen süre zarfında, yeni binalarda standartlara uyum sağlandığı söylenebilmekle beraber mevcut binalar için aynı durumdan bahsedilemez. Mevcut binalarda, mühendislik hizmeti alınmadan, denetimden uzak bir şekilde işinin ehli olmayan kişilerce mantolama imalatlarına devam edilmektedir. Isı yalıtımı uygulamaları yönetmelik ve standartlarda belirtilen kurallara uygun bir şekilde yapılmadığı taktirde, ısıtma ve soğutma için enerji sarfiyatı beklenilenin üzerinde oluşmaktadır. 
Günümüzde ıSı yalıtım uygulamalarının önemi bilinmesine rağmen, bina sahipleri ve yöneticileri tarafından mevzuata ve mühendislik kurallarına uygun olmayan uygulamaların yapıldığı görülmektedir. Isı yalıtımı konusunda toplumda oluşturulan yanlış algının önüne geçilebilmesi için, öncelikle kamu kurum ve kuruluşlarınca basın, yayın ve iletişim organları vasıtasıyla tanıtıcı bilgilere yer verilmelidir.

Genel olarak mevcut binalarda, Isı yalıtımının sadece bina dış cephelerinde mantolama şeklinde uygulandığını görmekteyiz. Ancak, yalıtım sadece bina dış cephesiyle değil çatı, teras ve penceresi ile bir bütündür. Bu nedenle, ilgili yönetmelikler ve TS 825 'de belirtilen hususlara uygun olarak öncelikle mühendislik hizmetlerinden faydalanılmak suretiyle tadilat projelerinin hazırlanıp, ilgili idarelerce tadilat ruhsatının onaylanması akabinde uygulamaların işinin ehli kişilerce yapılması ve titizlikle denetlenmesi önem arz etmektedir.

Enerji tasarrufu için alınacak önlemlerin genişletilmesi ve doğru bir şekilde uygulanabilirliğinin arttırılması amacıyla, konunun standart ve kurallarını belirleyen kamu kurum ve kuruluşları ile araştırma ve geliştirme faaliyetlerinde bulunan üniversitelerin birlikte çalışmaları gerekmektedir.

\section{KAYNAKLAR}

BIB (2008). Binalarda Enerji Performansı Yönetmeliği ve Binalarda Isı Yalıtımı Yönetmeliği. T.C. Bayındırlık ve İskan Bakanlığı, Ankara.

ÇŞB (2015). Isı Yalıtım Uygulama Kılavuzu, T.C. Çevre ve Şehircilik Bakanlığı, Ankara.
ÇSGB (2014). İş Sağlığı ve Güvenliğine İlişkin İşyeri Tehlike Sınıfları Tebliğinde Değişklik Yapılmasına Dair Tebliğ. T.C. Çalışma ve Sosyal Güvenlik Bakanlığı, Ankara.

ETKB (2007). 5627 Sayılı Enerji Verimliliği Kanunu. T.C. Enerji ve Tabii Kaynaklar Bakanlığı, Ankara.

ETKB (2015). Enerji ve Tabii Kaynaklar Bakanlığı 2014 Yılı Faaliyet Raporu, T.C. Enerji ve Tabii Kaynaklar Bakanlığı, Ankara.

Koçu, N., Dereli, M. (2010). Dış Duvarlarda Isı Yalıtımı İle Enerji Tasarrufu Sağlanması Ve Detaylarda Karşılaşılan Sorunlar (Konya Kentinden Öneriler), 5. Ulusal Çatı \& Cephe Sempozyumu, DEÜ İzmir.

Oral, G. K., Manioğlu, G. (2010). Bina Cephelerinde Enerji Etkinliği ve Isı Yalıtımı, 5. Ulusal Çatı \& Cephe Sempozyumu, DEÜ İzmir.

Şenkal, F.S., (2005). Türkiye'de Isı Yalıtımının Gelişimi ve Konutlarda Uygulanan Dış Duvar Isı Yalıtım Sistemleri, Uludağ Üniversitesi Mühendislik-Mimarlık Fakültesi Dergisi, 10(2): 79-85.

TS 825, (2013). Binalarda Isı Yalıtım Kuralları, Türk Standartları Enstitüsü, Ankara.

URL-1 (2016). Yalıtım Hakkında Bilgi Almak İstiyorum. http://www.izoder.org.tr/tr/bilgi-merkezi/isi-yalitimi/genelbilgi-almak-istiyorum/index.asp, [Erişim Tarihi: 09 Ocak 2016]

URL-2 (2016). Neden Isı Yalıtımı Yaptırmalıyız. http://www.izoder.org.tr/tr/dokumanlar/isi_yalitimi/isiyalitimi.pdf, [Erişim Tarihi: 09 Ocak 2016]

URL-3 http://www.bep.gov.tr/BEPTRWEB/SSSDetay.aspx\#.VpA nyrA5mM8, [Erişim Tarihi: 8 Ocak 2016]

URL-4 (2016). http://www.izocam.com.tr/, [Erişim Tarihi: 10 Ocak 2016]

URL-5 (2016). http://www.xpsturkiye.org/foto-galeri.asp, [Erişim Tarihi: 10 Ocak 2016]

URL-6 (2016). http://www.insaatbirdal.com/uygulamalarimiz, [Erişim Tarihi: 17 Ocak 2016]

Yaman, Ö., Şengül, Ö., Selçuk, H., Çalıkuş, O., Kara, İ., Erdem, Ş., Özgür, D. (2015). Binalarda Isı Yalıtımı ve Isı Yalıtım Malzemeleri, Türkiye Mühendislik Haberleri (TMH), Sayl: 487, 62-75s., İstanbul. 